\title{
Application of a simulation model for assessing integration of smallholder shifting cultivation and sheep production in Yucatán, Mexico
}

\author{
David Parsons $^{\mathrm{a}, *}$, Charles F. Nicholson ${ }^{\mathrm{b}}$, Robert W. Blake ${ }^{\mathrm{c}}$, Quirine M. Ketterings ${ }^{\mathrm{d}}$, Luis Ramírez-Aviles ${ }^{\mathrm{e}}$, \\ Jerome H. Cherney ${ }^{\text {f }}$, Danny G. Fox ${ }^{\mathrm{d}}$ \\ a School of Agricultural Science, University of Tasmania, Australia \\ ${ }^{\mathrm{b}}$ Department of Agribusiness, California Polytechnic State University, San Luis Obispo, USA \\ ${ }^{\mathrm{C}}$ Center for Latin American and Caribbean Studies, Michigan State University, USA \\ ${ }^{\mathrm{d}}$ Department of Animal Science, Cornell University, USA \\ ${ }^{\mathrm{e}}$ Facultad de Medicina Veterinaria y Zootecnia, Universidad Autónoma de Yucatán, Mexico \\ ${ }^{\mathrm{f}}$ Department of Crop and Soil Sciences, Cornell University, USA
}

\begin{abstract}
Simulation models are effective tools to examine interactions between livestock, cropping systems, households, and natural resources. Our study objective was to use an integrated livestock and crop model to assess the outcomes from selected suites of management decisions observed in smallholder sheepcropping systems of Yucatán, Mexico. The scenarios contrasted specialized systems versus mixed farming, and evaluated the outcomes of increased crop-livestock integration. Mixed enterprise scenarios involving sheep provided more income than specialized enterprises, and capitalized on a lower price of on-farm maize grain, efficient utilization of surplus labor, and availability of common land. Labor and management income was greatest for the unintegrated and partially integrated crop and livestock scenarios. It was more profitable for producers to sell excess grain and maize stover, and use common land to feed the livestock, suggesting that increased integration does not always result in improved outcomes. The results are consistent with a system not yet pushed to the point where integration is inevitable. For all sets of scenarios, the model structure was able to accommodate subtle management differences to produce appropriate biophysical, labor, and economic outcomes. We conclude there is potential to use similar model development methods to describe other crop-livestock systems, thus providing tools for learning, scenario analysis, and impact assessment.
\end{abstract}

\section{Introduction}

Delgado et al. (1999) used the term 'livestock revolution' to describe a future where population growth, urbanization, and income growth in developing countries lead to rapid increases in demand for food of animal origin. This situation presents both opportunities and challenges. Livestock offer benefits to society in the form of food, fibre, nutrient cycling, employment, and insurance (Herrero et al., 2009). There is the potential to alleviate poverty if the world's poor can successfully participate in livestock production and marketing. On the other hand, livestock have been associated with potential negative consequences for the environment, including using a significant amount of land, forest conversion, soil erosion or compaction, greenhouse gas emissions, and water pollution (Nicholson et al., 2001; Herrero et al., 2009). Moreover, the implications of evolution in livestock production and marketing systems for household welfare (including labor allocation and income) are likely to depend on individual household characteristics as well as the economic and environmental context.

Thus, it is important to evaluate potential changes in livestock systems in a site-specific manner, avoiding overly speculative generalizations about livestock, production systems, households, and the environment. However, there is wisdom in building on principles derived from similar situations and comparative study. The conceptual models developed by the livestock and environment toolbox (Morton, 2001) are useful examples of this approach. Sterman (2000) argued that conceptual models are useful, but that simulation modeling often is the only practical method to understand the likely dynamic implications of interventions in a complex system. Because the development of simulation models for crop-livestock systems usually requires much more effort than conceptual models, Thornton and Herrero (2001) argued in favor of generalizable models. They proposed a framework for the integration of detailed crop-livestock models as a step towards development of generic models that can be applied to numerous circumstances. The model development procedure described in 
the companion paper was influenced by this aspiration. Although our integrated model is specific to a particular region and combination of agricultural practices, the component models used and the modeling approach have potential application to be used to describe other situations.

The benefits and drawbacks of crop-livestock integration have been addressed by numerous previous authors (e.g. Powell and Williams, 1995; McIntire et al., 1992). Simulation modeling offers a useful approach to assessing the dynamic effects of integration, but its application to this question has been relatively limited. Our objective was to examine the biophysical and economic implications of increasing levels of sheep and crop production integration using a dynamic simulation model (described in the companion paper).

Milpa, the traditional shifting cultivation system, in Yucatán, Mexico, is undertaken using common land. Preparation of the mil$p a$ is a labor-intensive process, under which an area of forest is cut, burned, and planted to maize (Zea mays L.), often grown in polyculture with squash (Cucurbita pepo L.) and beans, such as 'ib' (Phaseolus lunatus L.) and 'xpelón' (Vigna unguiculata L. Walp.). Generally a two (or sometimes three) year cultivation period is followed by a 10-20-year period of forest fallow (Kessler, 1990). The buildup of nitrogen under the leguminous forest fallow and the ash from the burning process provide nutrients, and weed pressure in the freshly cleared plot is low. After several years of cultivation, increasing weed pressure and decreasing fertility result in yield decline (Parsons et al., 2009), and the land is abandoned to forest fallow. Milpa production is primarily for home consumption, although excess grain may be used for livestock production or sold.

Livestock ownership, including horses, cattle, hogs, fowl, and bees, has long been a part of traditional agriculture (Steggerda, 1941). Production of hair sheep is a more recent practice that is becoming increasingly common, with potential to diversify income and access potential complementarities between cropping and livestock. Parsons et al. (2006) conducted a survey of smallholder sheep farmers in Yucatán and described their practices and the nature of some of the interactions between cropping and livestock. An important feature of the farms was their diversity, including contrasting methods of feeding, and different intensities of crop and forage production, integration with cropping, and investment in infrastructure.

A number of pathways for livestock integration are evident in practice, and two of these are analyzed using the integrated model in this paper. The survey of Parsons et al. (2006) revealed that $44 \%$ of producers reported the use of maize stover (either cut and carry or utilized in-field) and $18 \%$ of producers reported the use of maize grain. Secondary crop products such as pumpkins and beans are less commonly used for feeding sheep. In contrast to the fairly common use of crop products, virtually no farmers reported use of manure on milpa. Use of manure in home gardens or on forages was more commonly reported, but in total only one-third of producers reported any form of manure use. This is unusual considering that virtually every producer pens sheep in corrals either permanently or during the night, resulting in manure accumulation. Sheep pens and small areas of cultivated forage are often located on private land close to the house (and home garden), whereas milpas are usually located on common land some distance from the house. Thus, it is likely to be physically easier to apply manure to home gardens and forage than crops. In addition, the long-term benefits of manure use are unlikely to be realized by a producer who abandons the land after 2 years.

\section{Methods and scenario descriptions}

We used the integrated model described in the companion paper to evaluate the effect of livestock ownership, and crop-livestock integration, on key biophysical and economic outcomes. Our intention was to be descriptive of the system and simulate outcomes given specific farmer decision scenarios, but not prescriptive (prescribing what farmers should be doing). The integrated model assesses typical scenarios rather than specific farmer cases. Farmer case studies are valuable in characterizing sets of actual practices. However, the results can be harder to interpret and apply to other situations. With scenario analysis more variables are controlled, enabling a more direct comparison of the outcomes of changing a selected set of variables. This approach enables the principles to be interpreted more generally, rather than applicable only to very similar farms.

\subsection{Description of scenarios}

The five scenarios analyzed include specialized milpa production, specialized sheep production, mixed but unintegrated milpa and sheep production, partially integrated milpa and sheep production, and fully integrated milpa and sheep production. The key parameters of the scenarios are contained in Table 1, and include available land, price and allocation of capital items, target (maximum) sheep numbers, initial inventories of maize grain and stover, and threshold inventory levels at which maize grain and stover are sold. Each scenario is described below.

(a) Milpa only - For many farmers, in addition to a small home garden, the only significant agricultural practice is milpa, with no income from livestock. To represent this scenario an area of 2 ha is cultivated, which is within the typical range for households in the region (Parsons et al., 2006). In the integrated model, for first year maize crops, the soil nitrogen, and soil and surface organic matter are reset to levels that represent freshly cleared forest. The second year crop is sown into the same soil as the first year crop, with increased competition from weeds, and at the end of the second year the soil characteristics are reset to represent land after fallow.

(b) Sheep production only - This scenario represents specialist sheep producers, with no crop cultivation. Consistent with commonly-observed practice of producers in the region (Parsons et al., 2006), manure is neither used nor sold. In this scenario the producer has 12 ewes, one ram, and a variable number of growing stock, which are fattened and sold only once breeding flock targets are reached. The sheep are predominantly fed by cut and carry of native grasses and legumes from common land in the dry season, and by grazing of common land in the wet season. In addition, lambs and growing ewes are fed maize grain in order to achieve reasonable growth rates. Although farmers in the region exhibit great variety in feeding options (Parsons et al., 2006), this combination of feeding represents commonlyobserved practices. Harvesting tree foliage is common $(90 \%$ of households) and a wide range of species is collected, many of which are leguminous. Harvesting of tree foliage is particularly important during the dry season, when other feed resources are scarce. The most common source of tree foliage is common land (such as forests); however foliage is also collected from private land, particularly the home garden, and may also be purchased.

(c) Unintegrated milpa and sheep - Parsons et al. (2006) found $75 \%$ of sheep producers surveyed also cultivated a milpa, and thus the third scenario is a combination of the first two scenarios. A milpa is cultivated as in the first scenario and sheep are managed in the same manner as the second scenario; however crop and sheep enterprises are not integrated through either crop by-product or manure use. This 
Table 1

Values of key parameters used to define scenarios for evaluating the outcomes of livestock ownership and crop-livestock integration in Yucatán Mexico.

\begin{tabular}{|c|c|c|c|c|c|c|}
\hline Name & Units & Milpa only & Sheep only & $\begin{array}{l}\text { Unintegrated milpa } \\
\text { and sheep }\end{array}$ & $\begin{array}{l}\text { Partially integrated milpa } \\
\text { and sheep }\end{array}$ & $\begin{array}{l}\text { Integrated milpo } \\
\text { and sheep }\end{array}$ \\
\hline Allocation of storeroom costs to milpa & $\%$ & 100 & 0 & 50 & 50 & 50 \\
\hline Area of milpa & ha & 2 & 0 & 2 & 2 & 2 \\
\hline Corral capital costs & MXN & 0 & 1000 & 1000 & 1000 & 1000 \\
\hline Target number of ewes & Sheep & 0 & 12 & 12 & 12 & 12 \\
\hline Target number of rams & Sheep & 0 & 1 & 1 & 1 & 1 \\
\hline Initial maize grain inventory & $\mathrm{kg} \mathrm{DM}$ & 0 & 0 & 800 & 800 & 800 \\
\hline Maize grain inventory sale threshold & $\mathrm{kg} \mathrm{DM}$ & 0 & 0 & 2100 & 2100 & 2100 \\
\hline Initial maize stover inventory & $\mathrm{kg} \mathrm{DM}$ & 0 & 0 & 0 & 0 & 4000 \\
\hline Maize stover inventory sale threshold & $\mathrm{kg}$ DM & 0 & 0 & 0 & 0 & 5000 \\
\hline Date of manure application & & - & - & - & 1 June & 1 June \\
\hline
\end{tabular}

Table 2

Values of economic constants used to model mixed crop-livestock household scenarios in Yucatán Mexico.

\begin{tabular}{lll}
\hline Constant & Units & Value \\
\hline Commercial supplement as-fed purchase price & MXN kg-1 & 2.8 \\
Cull ewe price & $\mathrm{MXN} \mathrm{kg}^{-1}$ & 12 \\
Cull ram price & $\mathrm{MXN} \mathrm{kg}^{-1}$ & 12 \\
Sheep finished price & $\mathrm{MXN} \mathrm{kg}^{-1}$ & 25 \\
Flock health cost per sheep & $\mathrm{MXN} \mathrm{day}^{-1}$ sheep $^{-1}$ & 0.05 \\
Maize grain as-fed purchase price & $\mathrm{MXN} \mathrm{kg}^{-1}$ & 3.51 \\
Maize grain as-fed sale price & $\mathrm{MXN} \mathrm{kg}^{-1}$ & 3.20 \\
Maize stover as-fed purchase price & $\mathrm{MXN} \mathrm{kg}^{-1}$ & 0.66 \\
Maize stover as-fed sale price & $\mathrm{MXN} \mathrm{kg}$ & 0.66 \\
Risk free rate of interest & $\%$ per year & 7 \\
\hline
\end{tabular}

is an important scenario to include because it is representative of numerous producers, who practice both but choose not to integrate.

(d) Partially integrated milpa and sheep - The fourth scenario also includes both crop and sheep production. We refer to it as partially integrated because manure is applied to the milpa before planting; however crop residues from the milpa are not used for sheep production. This is currently not representative of many producers for reasons discussed above.

(e) Fully integrated milpa and sheep - The fifth scenario also includes both crop and sheep production; however maize stover is used to feed growing rams, mature rams, and mature ewes in the dry season. To compensate for the poor quality of maize stover (compared to the feed resources available from common land), enough commercial concentrate is added to maintain body condition. In addition, like the previous scenario, manure is applied to the milpa before planting. This combination of farming practices is also not commonly observed in the region; however we included it as an example of how crop-livestock integration may develop in the future with decreased common land availability.

For each scenario, key biophysical and socioeconomic outcomes are assessed. Biophysical outcomes focus on nutrient flows, maize grain and stover production, livestock feed intake and production, manure, and refused feed. The socioeconomic outcomes include labor, enterprise expenses, net cash income, and labor and management income (LMI). Net cash incomes for the milpa and sheep enterprises are calculated without accounting for the value of internal transfers between enterprises. Labor and management income is what remains of the household net income after a fair return to the household's equity in capital items and land is subtracted, and is an appropriate indicator because it takes into account both net income and the opportunity cost of capital. The values in Mexican Pesos (MXN) for economic constants are shown in Table 2 and 1 USD = 12.3 MXN. Despite its nutrient content and potential contribution to crop yields, manure is not typically sold so we assumed a value of zero for manure for internal transfer. Although internal transfers influence the relative returns to each enterprise they do not affect farmer decision making in the model, or the overall financial performance of the farm.

\section{Results}

\subsection{Maize production}

For the specialized milpa scenario the average quantity of maize grain produced (Table 3) was $1436 \mathrm{~kg} \mathrm{DM} \mathrm{year}^{-1}$, the entire amount of which was sold off-farm because of the absence of sheep. For the unintegrated milpa and sheep scenario the same quantity of grain was produced, but a lesser amount $\left(570 \mathrm{~kg} \mathrm{DM} \mathrm{year}^{-1}\right)$ of grain was sold off-farm, approximately half ( $752 \mathrm{~kg} \mathrm{DM} \mathrm{year}^{-1}$ ) was used on-farm for feeding livestock, and the balance was retained in storage. For the partially and fully integrated milpa and sheep scenarios a small quantity of extra grain was produced due to the application of manure, and this increased the quantity sold off-farm. For the specialized sheep scenario the entire quantity of grain fed was purchased off-farm. The average nitrogen concentration of maize grain was high, and similar for all scenarios, ranging from 13.5 to $13.8 \mathrm{~kg} \mathrm{~N}(\mathrm{~kg} \mathrm{DM})^{-1}$.

The average quantity of maize stover produced (Table 3 ) was $4676 \mathrm{~kg} \mathrm{DM} \mathrm{year}^{-1}$ for the specialized milpa and the unintegrated milpa and sheep scenarios, because all production parameters for maize were identical. For the partially and fully unintegrated milpa and sheep scenarios, although the addition of manure resulted in increased grain yield, the stover yield was not significantly increased. The average maize stover nitrogen concentration was similar for all scenarios. The results for maize stover represent little difference among scenarios in either the quantity or quality of stover available.

The average pattern of nitrate availability in milpa is shown in Fig. 1. Year 1 is the first maize crop grown in an area of recently cleared maize, and year 2 is the second maize crop, grown in the same location the year after the first maize crop. The initial nitrate concentration is greater for first than second year crops, due to a negative nitrogen balance in the first year crop. The initial nitrate concentration is also greater for integrated than non-integrated scenarios, due to manure addition. Around the time the crop is sown in early June the nitrate concentration begins to decline, and is very low by the time the crop is harvested in September or October. Although water stress is the major limitation to plant growth (results not shown) nitrogen is limiting maize production for each of these combinations, even those with manure addition. This partially confirms why producers typically abandon fields after 2 years - even though there is an increase in nitrogen due to organic matter mineralization following harvest there is a marked decrease in available nitrogen between the first and 
Table 3

Mean simulated values of key biophysical outputs from crop-livestock integration scenarios in Yucatán Mexico.

\begin{tabular}{|c|c|c|c|c|c|c|}
\hline Biophysical output & Units & Milpa only & Sheep only & $\begin{array}{l}\text { Unintegrated milpa } \\
\text { and sheep }\end{array}$ & $\begin{array}{l}\text { Partially integrated milpa } \\
\text { and sheep }\end{array}$ & $\begin{array}{l}\text { Integrated milpa } \\
\text { and sheep }\end{array}$ \\
\hline \multicolumn{7}{|l|}{ Maize } \\
\hline Maize grain produced & $\mathrm{kg} \mathrm{DM}$ year $^{-1}$ & 1436 & 0 & 1436 & 1579 & 1593 \\
\hline Produced maize grain sold off-farm & $\mathrm{kg} \mathrm{DM} \mathrm{year}^{-1}$ & 1436 & 0 & 570 & 715 & 729 \\
\hline Produced maize grain fed & $\mathrm{kg} \mathrm{DM}$ year $^{-1}$ & 0 & 0 & 752 & 750 & 750 \\
\hline Total maize grain fed & $\mathrm{kg} \mathrm{DM} \mathrm{year}^{-1}$ & 0 & 754 & 752 & 750 & 750 \\
\hline Maize grain purchased off-farm & $\mathrm{kg} \mathrm{DM} \mathrm{year}^{-1}$ & 0 & 754 & 0 & 0 & 0 \\
\hline Maize grain nitrogen concentration & $\mathrm{g} \mathrm{N} / \mathrm{kg} \mathrm{DM}$ & 13.5 & 13.6 & 13.5 & 13.8 & 13.8 \\
\hline Maize stover produced & $\mathrm{kg} \mathrm{DM} \mathrm{year}^{-1}$ & 4676 & 0 & 4676 & 4640 & 4648 \\
\hline Produced maize stover fed & $\mathrm{kg} \mathrm{DM} \mathrm{year}^{-1}$ & 0 & 0 & 0 & 0 & 3700 \\
\hline $\begin{array}{l}\text { Maize stover nitrogen concentration } \\
\text { Livestock }\end{array}$ & $\mathrm{g} \mathrm{N} / \mathrm{kg} \mathrm{DM}$ & 10.2 & - & 10.2 & 10.6 & 10.6 \\
\hline Feed intake of male fattening (dry season) & g DM/day & - & 990 & 990 & 990 & 990 \\
\hline Feed intake of male fattening (wet season) & g DM/day & - & 1010 & 1010 & 1010 & 1010 \\
\hline Feed intake of growing rams (dry season) & g DM/day & - & 1170 & 1170 & 1170 & 1160 \\
\hline Feed intake of growing rams (wet season) & g DM/day & - & 1200 & 1200 & 1200 & 1200 \\
\hline Growth rate of male fattening (dry season) & $\mathrm{g} \mathrm{day}^{-1}$ & - & 95 & 95 & 95 & 95 \\
\hline Growth rate of male fattening (wet season) & g day $^{-1}$ & - & 110 & 110 & 110 & 110 \\
\hline Growth rate of growing rams (dry season) & $\mathrm{g} \mathrm{day}^{-1}$ & - & 109 & 109 & 109 & 99 \\
\hline Growth rate of growing rams (wet season) & $\mathrm{g} \mathrm{day}^{-1}$ & - & 128 & 128 & 128 & 128 \\
\hline \multicolumn{7}{|l|}{ Manure and refused feed } \\
\hline Dung production & $\mathrm{kg} \mathrm{DM} \mathrm{year}^{-1}$ & 0 & 4365 & 4365 & 4365 & 4424 \\
\hline Carbon in dung production & $\mathrm{kg} \mathrm{C} /$ year & 0 & 2118 & 2119 & 2119 & 2156 \\
\hline Nitrogen in dung production & $\mathrm{kg} \mathrm{N} /$ year & 0 & 72.6 & 72.6 & 72.6 & 74.5 \\
\hline $\mathrm{C}: \mathrm{N}$ of dung & $\mathrm{kg} \mathrm{C} / \mathrm{kg} \mathrm{N}$ & - & 29.2 & 29.2 & 29.2 & 29.0 \\
\hline Nitrogen in urine production & $\mathrm{kg} \mathrm{N} /$ year & 0 & 58.8 & 58.8 & 58.8 & 63.1 \\
\hline Manure applied to crop & $\mathrm{kg} \mathrm{DM} \mathrm{year}^{-1}$ & 0 & 0 & 0 & 3571 & 3737 \\
\hline $\mathrm{C}: \mathrm{N}$ of manure applied to crop & $\mathrm{kg} \mathrm{C} / \mathrm{kg} \mathrm{N}$ & - & - & - & 30 & 29.7 \\
\hline Refused feed & kg DM year $^{-1}$ & 0 & 2230 & 2230 & 2230 & 3837 \\
\hline
\end{tabular}

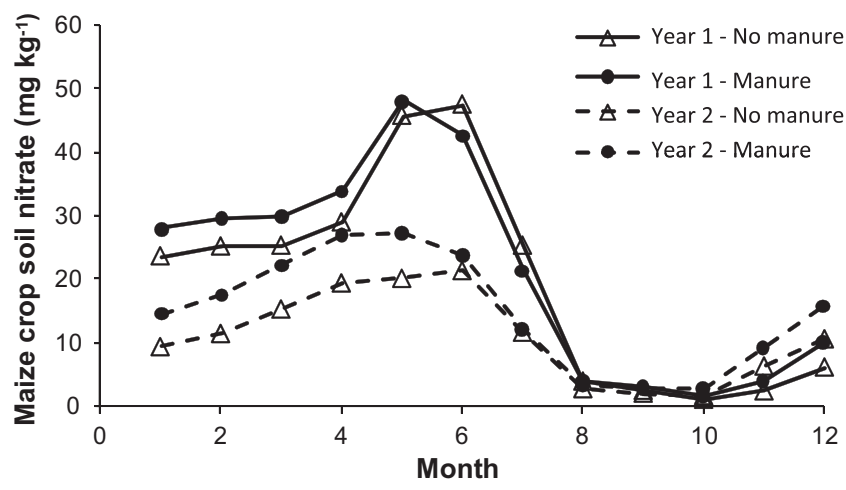

Fig. 1. Average monthly maize crop soil nitrate concentrations for four types of milpa crop, in Yucatán Mexico. Year 1 is the first maize crop grown in an area of recently cleared maize. Year 2 is the second maize crop, grown in the same location the year after the first maize crop.

second years of cultivation. Improved yields could potentially be attained by adding more nitrogen, possibly in the form of urea, however for continued cultivation the issue of weed infestation would also need to be addressed (Parsons et al., in press).

\subsection{Livestock production}

Simulated livestock outputs for one class of fattening animal (male fattening) and one class of breeding animal (growing rams) indicate differences among the scenarios (Table 3). For both classes of sheep, feed intake was greater during the wet season than the dry season, due to superior feed quality (i.e. higher energy and protein concentrations) of the available native vegetation. Feed intake for male fattening sheep was the same across all sheep scenarios because of identical diets. For the fully integrated milpa and sheep scenario, rams and mature ewes were fed a diet including stover.
The feed intake for growing rams during the dry season was slightly lower for the integrated milpa and sheep scenario $\left(1160 \mathrm{~g} \mathrm{DM} \mathrm{day}^{-1}\right)$ than other scenarios $\left(1170 \mathrm{~g} \mathrm{DM} \mathrm{day}^{-1}\right)$. This is due to the superior feed quality of cut and carry feed from common land (which includes high protein species such as Leucaena leucocephala Lam.) compared to the poor quality of maize stover. This highlights the limited incentives for farmers to integrate through crop residues when better quality feed is available for free from common land. For the wet season the diets, and hence also the feed intakes for growing rams were the same for all scenarios.

For male fattening sheep, the growth rate (Table 3 ) for all scenarios was greater during the wet season $\left(110 \mathrm{~g} \mathrm{day}^{-1}\right)$ than the dry season $\left(95 \mathrm{~g} \mathrm{day}^{-1}\right)$. For growing rams, the growth rate was also greater during the wet season than the dry season. The poorer feed quality of the fully integrated milpa and sheep scenario resulted in a growing ram growth rate $20 \%$ less than for other scenarios. For this scenario, even though commercial concentrate is added to the ration to compensate for the low protein and energy concentration of maize stover, the feed quality is still limiting to growth compared to the cut and carry feed from common land.

\subsection{Manure and refused feed}

For all four scenarios with sheep, the manure outputs (Table 3) were very similar, because both the diets and number of sheep were similar. Dung production was $4365 \mathrm{~kg} \mathrm{DM} \mathrm{year}^{-1}$ for the specialized sheep scenario, the unintegrated, and the partially integrated milpa and sheep scenario. Dung production for the fully integrated milpa and sheep scenario was $37 \mathrm{~kg} \mathrm{DM}$ year $^{-1}$ greater, due to the lower digestibility of maize stover compared with other feeds, but the practical difference is negligible. Carbon and nitrogen in dung production and nitrogen in urine were also similar enough among scenarios to be of little practical consequence.

For the integrated milpa and sheep scenarios manure is only applied once per year to the surface of the milpa field. Fig. 2 shows that the pattern of breakdown of manure is similar among years, with 


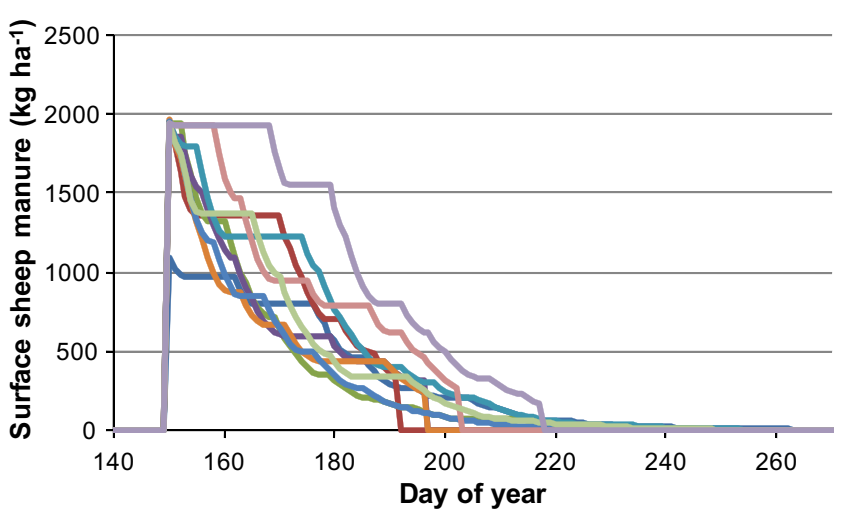

Fig. 2. The change in the quantity of sheep manure on the surface of the soil in a milpa field, in Yucatán Mexico. Each line represents a different year of the 10-year simulation.

differences due to environmental factors, particularly rainfall, affecting decomposition rate. Maize was on average harvested on day 273 , and very little surface manure remained by this time. The quantity of manure applied to the milpa averaged $3737 \mathrm{~kg} \mathrm{DM}$ year $^{-1}$, which is $84 \%$ of the total manure produced annually; thus $16 \%$ of manure was lost during the storage process, with no change in the $\mathrm{C}: \mathrm{N}$ ratio. The loss of manure and nitrogen is unsurprising given that the manure was not covered, and is supported by data from Gichangi et al. (2007) in Central Kenya where as much as $40 \%$ of total $\mathrm{N}$ is lost where manure heaps are exposed to heat and rain. This is an issue that could be addressed with improved methods for manure management, such as covered heaps and incorporation of agro-organic wastes.

Refused feed is feed that is offered to the animal that is not eaten. The quantity of refused feed was $2230 \mathrm{~kg} \mathrm{DM}_{\text {year }}{ }^{-1}$ for the specialized sheep scenario and the unintegrated and partially integrated milpa and sheep scenarios. Refused feed for the integrated milpa and sheep scenario was notably greater, due to the use of maize stover in the dry season, a high proportion of which is refused.

\subsection{Labor requirements}

Because the management practices were identical, the specialized milpa and the unintegrated milpa and sheep scenarios required the same average daily labor (Table 4) for milpa activities $\left(2.9 \mathrm{~h} \mathrm{day}^{-1}\right)$. The average labor required for the integrated scenarios was slightly greater $\left(3.0 \mathrm{~h} \mathrm{day}^{-1}\right)$ because of the necessity of labor for application of manure to the milpa. Average labor for the specialized milpa scenario was only half of the household labor available for milpa, suggesting that labor is underutilized. However, because milpa cultivation is seasonal, additional milpa cultivation is constrained by lack of labor during the dry season before the first year of a milpa when a large amount of labor is required for preparation. Seasonality of milpa cultivation is also relevant in mixed scenarios, but total available household labor is greater in these scenarios because children and women who will generally not help with the milpa will often help with livestock (Author pers. obs.).

For the sheep only scenario the total labor input was 3.1 h day $^{-1}$, suggesting that there is unutilized household labor, which potentially could be exploited through larger flock sizes. For all scenarios with sheep, grazing supervision during the wet season was the greatest component of sheep enterprise average daily labor $\left(1.5 \mathrm{~h} \mathrm{day}^{-1}\right)$. In comparison, cut and carry labor was $0.4 \mathrm{~h} \mathrm{day}^{-1}$, (averaged across the year) but would increase with a larger flock of sheep, unlike grazing supervision labor. Total aver- age daily labor was greatest for the mixed scenarios, due to the combination of both enterprises.

\subsection{Milpa and livestock enterprise expenditures}

Infrastructure costs are defined as the annual costs of fixed inputs. Livestock infrastructure costs include irrigation infrastructure, fencing, improved pasture, corrals, and a storeroom, whereas milpa infrastructure costs only include a storeroom. For the milpa only scenario the average expenditures $\left(0.9 \mathrm{MXN} \mathrm{day}^{-1}\right)$ consisted only of infrastructure costs (Table 4). Milpa expenditures were lower for the unintegrated milpa and sheep scenario $\left(0.5 \mathrm{MXN} \mathrm{day}^{-1}\right)$ because storeroom expenses could be shared with the livestock enterprise. Milpa expenses were greater for the integrated milpa and sheep scenarios (1.3 $\mathrm{MXN}$ day $\left.^{-1}\right)$ because of the additional cost of hired labor for manure application.

Average livestock enterprise expenditures (Table 4) were 11.1 MXN day $^{-1}$ for the specialized sheep scenario, most of which $\left(8.1 \mathrm{MXN} \mathrm{day}^{-1}\right.$ ) consisted of purchased feeds, and the remainder flock health and livestock infrastructure expenditures. In comparison with the specialized sheep scenario, for the unintegrated and partially integrated milpa and sheep scenarios the livestock infrastructure expenditure was slightly less due to shared infrastructure expenditures. In addition, the purchased feed expenditure was $0.7 \mathrm{MXN}$ day $^{-1}$ less because maize grain is sourced on-farm rather than purchased, with the lower transaction costs resulting in a small difference in purchase price. For the fully integrated milpa and sheep scenario the livestock expenditure was more than twice that of other scenarios, due to a much greater purchased feed expenditure resulting from the commercial concentrate needed in the diet to maintain body condition for sheep consuming maize stover.

\subsection{Net cash income}

Milpa net cash income was greatest (24.5 $\mathrm{MXN} \mathrm{day}^{-1}$ ) for the specialized milpa scenario (Table 4). For the unintegrated and partially integrated milpa and sheep scenarios it was approximately $8 \mathrm{MXN} \mathrm{day}^{-1}$ less because net cash income does not account for the internal transfer of maize grain. Similarly, for the integrated milpa and sheep scenario, although the maize grain yield was the greatest, the net cash income was only $8.4 \mathrm{MXN}$ day $^{-1}$ due to both maize grain and maize stover used by the livestock enterprise not being accounted for. For the same reasons that the internal transfers implied understated milpa net cash income for the mixed scenarios, the livestock net cash incomes for these scenarios were overstated. These results emphasize that although net cash income is a valid measure of total household income it is not an ideal measure for comparison of enterprise income because it can be influenced by internal transfers. For this reason the livestock net cash incomes will not be discussed in detail because labor and management income is a superior indicator of household and enterprise profitability.

\subsection{Labor and management income}

Average milpa LMI (Table 4) was 21.2 MXN day ${ }^{-1}$ for specialized milpa, slightly greater than for unintegrated milpa and sheep, due to the difference between internal transfer and sale price of maize grain. However, LMI for the specialized milpa was slightly less than for integrated milpa and sheep, due to increased maize production through manure use. This suggests that under current conditions there is a slight economic advantage for producers to apply manure to their crops, but possibly not enough to convince farmers who are not already doing this to change their practice. Average livestock LMI was $31.9 \mathrm{MXN} \mathrm{day}^{-1}$ for specialized sheep, and slightly 
Table 4

Mean simulated values of key socioeconomic outputs from crop-livestock integration scenarios in Yucatán Mexico.

\begin{tabular}{|c|c|c|c|c|c|c|}
\hline Socioeconomic output & Units & Milpa only & Sheep only & $\begin{array}{l}\text { Unintegrated milpa } \\
\text { and sheep }\end{array}$ & $\begin{array}{l}\text { Partially integrated milpa } \\
\text { and sheep }\end{array}$ & $\begin{array}{l}\text { Integrated milpa } \\
\text { and sheep }\end{array}$ \\
\hline \multicolumn{7}{|l|}{ Labor } \\
\hline Household labor input & $\mathrm{h}_{\text {day }}{ }^{-1}$ & 2.9 & 3.1 & 6.0 & 6.1 & 6.1 \\
\hline Livestock labor input & $\mathrm{h} \mathrm{day}^{-1}$ & 0.0 & 3.1 & 3.1 & 3.1 & 3.1 \\
\hline Cut and carry labor & $\mathrm{h}_{\text {day }}{ }^{-1}$ & 0.0 & 0.4 & 0.4 & 0.4 & 0.4 \\
\hline Grazing supervision labor & $\mathrm{h} \mathrm{day}^{-1}$ & 0.0 & 1.5 & 1.5 & 1.5 & 1.5 \\
\hline Sheep husbandry labor & $\mathrm{h}_{\text {day }}{ }^{-1}$ & 0.0 & 1.1 & 1.1 & 1.1 & 1.1 \\
\hline Milpa labor input & $\mathrm{h}_{\text {day }}{ }^{-1}$ & 2.9 & 0.0 & 2.9 & 3.0 & 3.0 \\
\hline \multicolumn{7}{|l|}{ Expenses } \\
\hline Livestock expenditures & MXN day ${ }^{-1}$ & 0.0 & 11.1 & 9.9 & 9.9 & 23.7 \\
\hline Livestock infrastructure & MXN day ${ }^{-1}$ & 0.0 & 1.2 & 0.8 & 0.8 & 0.8 \\
\hline Flock health & MXN day ${ }^{-1}$ & 0.0 & 1.8 & 1.8 & 1.8 & 1.8 \\
\hline Purchased feeds & MXN day ${ }^{-1}$ & 0.0 & 8.1 & 7.3 & 7.3 & 21.2 \\
\hline Milpa expenditures & MXN day ${ }^{-1}$ & 0.9 & 0.0 & 0.5 & 1.3 & 1.3 \\
\hline Hired labor for milpa & MXN day ${ }^{-1}$ & 0.0 & 0.0 & 0.0 & 0.8 & 0.8 \\
\hline Milpa infrastructure & MXN day ${ }^{-1}$ & 0.9 & 0.0 & 0.5 & 0.5 & 0.5 \\
\hline \multicolumn{7}{|l|}{ Income } \\
\hline Household net cash income & MXN day ${ }^{-1}$ & 24.5 & 37.1 & 61.7 & 61.9 & 48.0 \\
\hline Livestock net cash income & MXN day ${ }^{-1}$ & 0.0 & 37.1 & 45.2 & 45.2 & 39.7 \\
\hline Milpa net cash income & MXN day ${ }^{-1}$ & 24.5 & 0.0 & 16.5 & 16.7 & 8.4 \\
\hline Household labor and management income & MXN day ${ }^{-1}$ & 21.2 & 31.9 & 54.3 & 54.8 & 41.0 \\
\hline Livestock labor and management income & MXN day ${ }^{-1}$ & 0.0 & 31.9 & 33.4 & 33.4 & 19.5 \\
\hline Milpa labor and management income & MXN day ${ }^{-1}$ & 21.2 & 0.0 & 20.9 & 21.4 & 21.5 \\
\hline
\end{tabular}

greater for unintegrated and partially integrated milpa and sheep scenarios due to lower infrastructure and purchased feed expenditures. However, livestock LMI was the lowest for the integrated milpa and sheep scenario, primarily due to purchased feed expenditures. Total household LMI (milpa and livestock) was greater for specialized sheep $31.9 \mathrm{MXN} \mathrm{day}^{-1}$ than for specialized milpa. Total LMI was greater for mixed systems than specialized systems, due to the combined milpa and sheep net incomes, and greatest for the unintegrated and partially integrated milpa and sheep scenarios. The fully integrated scenario is less profitable than other mixed scenarios due to the increased commercial concentrate purchases required. The quantity of concentrate needed may be exaggerated because the model requires that protein and energy requirements are met to ensure positive growth, whereas in reality producers may let sheep lose weight at certain times of the year. However, even if the quantity of commercial concentrate is in excess of what farmers may actually use, the reality is that the combination of maize stover and concentrate is a costly source of energy and protein compared to the currently free resource of common land.

\section{Discussion and conclusions}

\subsection{Implications of specialized versus mixed farming systems for Yucatán}

The results suggest that scenarios involving sheep provide more labor and management income than milpa alone. This raises the question of why many farmers continue to cultivate a milpa if other opportunities (both agricultural and non-agricultural) appear to be a better investment. The reality is that few suitable employment opportunities may exist. There may be sporadic rural employment opportunities, or opportunities in nearby towns and cities, but these may not offer stability, or the timing or other circumstances may not suit many workers. The milpa has been the foundation of rural livelihoods for more than three millennia (Turner et al., 2003) and although it carries some risk, it is a fall-back system when other opportunities fail or are not available. Tradition and lack of exposure to new ideas and enterprise options are other potential reasons why farmers may continue to cultivate milpas instead of other seemingly more favorable opportunities. In addition, if the alternative enterprise were sheep, building a reasonably sized breeding flock from a small initial base could take producers a significant amount of time, even if all breeding animals were kept rather than sold. Producers would either require access to capital to be able to make a sizeable initial investment, or have another source of income to provide for household needs while stock numbers were increasing. Such additional research questions could be addressed with the integrated model.

The results indicate that sheep production can offer an alternative means of income generation in rural locations, with better income than milpa under current input and output market prices. Although not a focus of this study, our conversations with farmers revealed that sheep can provide a less seasonal source of income than crop production alone. We hypothesize that having a readily saleable asset like sheep could help smooth income and allow households to respond to various shocks for which they need income, as has been observed in other systems (Waithaka et al., 2006). The model is not able to test this hypothesis because the sheep are modeled in age-weight groups rather than as discrete animals, a feature that could be addressed in the future. In addition, as long as feeding resources are available, there are likely to be economies of scale for producers who can build up larger flocks, with potential to achieve greater income than those with small flocks.

Success in sheep production requires access to capital, markets, information, veterinary care, and other natural resources such as water, feed, and a sufficient area of common grazing land. The 'tragedy of the commons' (Hardin, 1968) has the potential to be a threat to the sustainability of Yucatán grazing systems, the extent of which is likely to vary spatially. Because most smallholder sheep producers keep their sheep in the village, accessing common forest land may require the sheep to walk a substantial distance. This is likely to result in overgrazing of common land close to villages, forcing sheep to graze further from the village as feed becomes limiting. The carrying capacity of the forest surrounding a village may ultimately limit the economic viability of sheep grazing, and is an area of study that warrants further investigation.

Our analyses indicated the origins and magnitudes of the benefits of specialized versus mixed systems. The results suggest that income can be greater for mixed farms than for specialized farms. This is achieved through use of surplus labor, reduced expenses 
(transaction costs) when maize grain is obtained on-farm rather than purchased, and, to a limited extent, sharing the cost of capital items.

Our analyses also suggested limits to increased integration. The first three scenarios simulated were based on representative farmer systems (Parsons et al., 2006) with typically limited biophysical integration between cropping and livestock. The last two scenarios include two pathways of integration, crop by-product use and manure use. Manure use resulted in small increases in crop yield (and consequently in profitability). This is consistent with the results of Parsons et al. (2009) who found small increases in yield with manure application, but also the potential for large increases in yield with a combination of manure and effective chemical weed control. Parsons et al. (in press) suggested that for continual cultivation of maize a manure rate of $4 \mathrm{Mg} \mathrm{DM} \mathrm{ha}^{-1}$ would be sufficient to sustain $\mathrm{P}$, but not $\mathrm{K}$ or $\mathrm{N}$; thus supplementary nutrient addition would be necessary. For the full integration scenario, it was more profitable for producers to not integrate through crop stover, and to instead use common land to feed the livestock and sell the maize stover rather than feed it. The results demonstrate that the highest degree of integration does not always result in optimal economic outcomes. These results are consistent with a system not yet pushed to the point where more complete integration is desirable. Under different circumstances, such as the reduced availability of common land, increased distance to travel to common land, or changed market prices, these outcomes may be different. It should also be noted that even the fully integrated scenario relies to a large extent on common land for feeding the majority of the sheep, and thus an even more integrated scenario is conceivable. McIntire et al. (1992) observed that crop-livestock activities become more integrated as population pressure increases and land becomes limiting. Parsons et al. (2006) found that many sheep farmers also cultivate a milpa (diversification), but limited integration exists, consistent with the current high availability of common land.

The results highlight the value of using simulation models for assessing the performance of crop-livestock systems, rather than relying on broadly applied principles of what is the most profitable and appropriate, for example the assumption that utilization of crop stovers for livestock production is necessarily advantageous.

\subsection{Value of the integrated model}

We applied the crop-livestock model described in the companion paper to scenarios examining specialized versus mixed systems, and increased integration. The model structure was able to capture the management differences between scenarios and reflect biophysical, labor, and economic outcomes and is thus a potentially valuable tool for learning, scenario analysis, and impact assessment. The model was developed for a specific system (smallholder sheep and cropping), and for a specific geographical location (Yucatán state, Mexico); however, the model development methods presented have potential for wider application, and could enable development of other system- and site-specific models. Ideally, an improved integrated model would be developed that would use the best available biophysical and economic models, but be easily adapted to represent unique system characteristics such as management, feed resources, crop production, and animal production.

\section{Acknowledgements}

The authors would like to thank a large number of farmers for contributing, particularly Leonardo Cocóm, Ángel Pool, and Víctor Casanova, who, in addition to their experience and expertise, offered their land and time for field experiments. A number of students from Universidad Autónoma de Yucatán helped with field work, particularly Yuliana del Carmen Herrera Tello. Felipe Torres-Acosta provided information to help calibrate model scenarios. The study was supported financially by Cornell University Department of Crop and Soil Sciences, a Richard Bradfield Research Award, an Andrew Mellon Student Research Grant, and funding from The Einaudi Center, The Latin American Studies Program, and The Cornell Institute for Food, Agriculture, and Development. The authors also thank two anonymous reviewers whose comments substantially improved the application of the model and its presentation.

\section{References}

Delgado, C., Rosegrant, M., Steinfeld, H., Ehui, S., Courbois, C., 1999. Livestock to 2020. The Next Food Revolution. Food, Agriculture, and the Environment. Discussion Paper 28. IFPRI/FAO/ILRI.

Gichangi, E.M., Karanja, N.K., Wood, C.W., 2007. Managing manure heaps with agroorganic wastes and cover to reduce nitrogen losses during storage on smallholder farms. In: Bationo, A., Waswa, B., Kihara, J., Kimetu, J. (Eds.), Advances in Integrates Soil Fertility Management in Sub-Saharan Africa: Challenges and Opportunities. Springer, Netherlands, pp. 611-618.

Hardin, G., 1968. The tragedy of the commons. Science 162 (3859), 1243-1248.

Herrero, M., Thornton, P.K., Gerber, P., Reid, B.S., 2009. Livestock, livelihoods and the environment: understanding the trade-offs. Current Opinion in Environmental Sustainability 1, 111-120.

Kessler, C.D.J., 1990. An agronomic evaluation of jackbean Canavalia ensiformis in Yucatán Mexico, I. Plant density. Experimental Agriculture 26, 11-22.

Morton, J., 2001. The electronic dissemination of policy information; experiences from the livestock-environment toolbox. Journal of International Development 13 (7), 877-891.

McIntire, J., Bourzat, D., Pingali, P., 1992. Crop-livestock Interaction in Sub-Saharan Africa. The World Bank, Washington, DC.

Nicholson, C.F., Blake, R.W., Reid, R.S., Schelhas, J., 2001. Environmental impacts of livestock in the developing world. Environment 43 (2), 7-17.

Parsons, D., Calderón-Quintal, A., Nicholson, C.F., Blake, R.W., López-Cervantes, C., Torres-Acosta, F., Cámara-Sarmiento, R., Ríos-Arjona, G., 2006. Diagnóstico y necesidades de investigación en los sistemas de producción ovinos en Yucatán. Universidad Autónoma de Yucatán.

Parsons, D., Ketterings, Q.M., Cherney, J.H., Blake, R.W., Ramírez-Aviles, L., Nicholson, C.F., in press. Effects of weed control and manure application on nutrient fluxes in the shifting cultivation milpa system of Yucatán. Archives of Agronomy and Soil Science.

Parsons, D., Ramírez-Aviles, L., Cherney, J.H., Ketterings, Q.M., Blake, R.W., Nicholson, C.F., 2009. Managing maize production in shifting cultivation milpa systems in Yucatán, through weed control and manure application. Agriculture, Ecosystems \& Environment 133 (1-2), 123-134.

Powell, M., Williams, T.O., 1995. An overview of mixed farming systems in SubSaharan Africa. In: Powell, J.M., Fernandez-Rivera, S., Williams, T.O., Renard, C. (Eds.), Livestock and Sustainable Nutrient Cycling in Mixed Farming Systems of Sub-Saharan Africa, Technical Papers. Proceedings of an International Conference held in Addis Ababa, Ethiopia, 22-26 November, 1993, vol. II. International Livestock Centre for Africa, Addis Ababa, Ethiopia.

Steggerda, M., 1941. Maya Indians of Yucatán. Publication \#531, Carnegie Institution of Washington, Washington, DC.

Sterman, J.D., 2000. Business Dynamics: Systems Thinking and Modeling for a Complex World. McGraw Hill, Boston.

Thornton, P.K., Herrero, M., 2001. Integrated crop-livestock simulation models for scenario analysis and impact assessment. Agricultural Systems 70, 581-602.

Turner II, B.L., Klepeis, P., Schneider, L.C., 2003. Three millennia in the Southern Yucatán Peninsula: implications for occupancy, use, and carrying capacity. In: Gomez-Pompa, A., Allen, M.F., Feddick, S.L., Jimenez-Osornio, J.J. (Eds.), The lowland Maya area, three millennia at the human-wildland interface. Food Products Press, Binghamton, NY, pp. 361-387.

Waithaka, M.M., Thornton, P.K., Herrero, M., Shepherd, K.D., 2006. Bio-economic evaluation of farmers' perceptions of viable farms in western Kenya. Agricultural Systems 90, 243-271. 